\title{
Trekk fra internasjonal psykiatrisk epidemiologi
}

\author{
Einar Kringlen \\ Psykiatrisk institutt, Vinderen, Oslo
}

\begin{abstract}
SAMMENDRAG
Den psykiatriske epidemiologis historie kan deles inn i tre faser. Den første fasen hadde sitt utspring $\mathrm{i}$ tysk psykiatri før første verdenskrig, var genetisk influert og bygget på alvorlig syke hospitaliserte pasienter fra de store asylene. Etter siste verdenskrig ble den psykiatriske epidemiologien, særlig i USA, sterkt påvirket av sosiologisk og antropologisk tenkning der sosial klasse og sosial desintegrering var viktige uavhengige variabler. Man er interessert $\mathrm{i}$ både alvorlig og lettere psykopatologi i den alminnelige befolkning. Siste fase inntrer etter 1970-80 og preges av opptatthet av psykiatrisk diagnostikk, standardiserte intervjuskjema og mer sofistikert statistikk. De større nyere studiene fra USA og Europa viser at psykiske lidelser er svært utbredt i befolkningen. Om lag 20 prosent av barn, voksne og eldre har såpass store psykiske problemer at det kvalifiserer for en psykiatrisk diagnose, og 50 prosent av befolkningen vil i løpet av livet utvikle en psykisk lidelse. Angstforstyrrelser og depresjon forekommer langt hyppigere hos kvinner enn hos menn, mens alkohol- og stoffmisbruk og antisosial atferd er hyppigst hos menn. Det har skjedd en klar økning av suicid, alkohol og stoffmisbruk gjennom de siste tiåra. Inntrykket er også at alminnelige depresjoner, antisosial atferd og spiseforstyrrelser i form av bulimi har økt. Dette er særlig bekymringsfullt siden økningen har funnet sted hos den yngre garde.
\end{abstract}

Kringlen E. Outlines of international psychiatric epidemiology. Nor J Epidemiol 2002; 12 (3): 173-179.

\section{ENGLISH SUMMARY}

The first phase of psychiatric epidemiology originated in German psychiatry before the first world war and was genetically informed and based upon severe hospitalized cases. After the second world war, psychiatric epidemiology was strongly influenced by sociological and social-anthropological thinking, especially in the United States. The studies were in general based upon samples from the general population, and one focused attention not only on psychoses but also on neurotic and sociopathic behaviour. During the 1970-80s psychiatric epidemiology entered a new phase. Standardized interview schemes and specific psychiatric diagnoses became important and sophisticated statistical analyses. Large-scale studies both from Europe and North America show that approximately 20 per cent of the population, children, adult and elderly, suffer from at least one mental disorder. More than 50 per cent of the population will develop a mental disorder in the course of their lifetime. One has witnessed an increase of suicide, alcohol- and substance abuse during the last decades. The clinical impression is also that common depressions, antisocial behaviour, and eating disorder, in particular bulimia, have been on the increase. The situation is worrisome since it is the young generation that is at risk.

Den psykiatriske epidemiologien omfatter studiet av utbredelsen av psykiske lidelser i befolkningen og risikofaktorer assosiert med begynnelse og forløp. Den psykiatriske epidemiologi er således et viktig vitenskapelig grunnlag for psykiatrien. Epidemiologien er selvsagt også interessert i tidsvariasjoner av psykiske lidelser, og hvordan disse fordeler seg etter alder, kjønn og sosial status. Epidemiologen forsøker altså å få et bilde av sykdom $i$ et samfunnsperspektiv.

To begrep er sentrale ved beregning av forekomst av sykdom i befolkningen. Prevalens angir andelen individer som har en spesiell sykdom på en bestemt tid. Ved livstidsprevalens er hele livsforløpet observasjonsperioden. Insidens angir antallet personer i en gitt befolkning som initialt er uten sykdom og som utvikler sykdom over en gitt tidsperiode, for eksempel et år.

\section{HisTORIKK}

En av de første psykiatrisk epidemiologiske studier ble utført av Jarvis i Massachusetts, USA, i 1855. Undersøkelsen som bygget på nøkkelinformanter, blant annet prester og sykehus, identifiserte 2632 "lunatics" og 1087 "idiots", som hadde behov for omsorg. I Norge utga legen Ludvig Dahl ${ }^{1}$ i 1859 en undersøkelse som var basert på offisiell statistikk og egne reiser i deler av landet. Mer raffinerte studier ble utført i Tyskland på begynnelsen av det 19. århundre. Det ble antatt at alvorlige psykiske lidelser var arvelig betinget. Epidemiologiske undersøkelser tok derfor blant annet sikte på å etablere arvegangen. Ernst Rüdin i München utviklet det som ble kalt "ärbliche Risiko-prognose", der man forsøkte å etablere tall for risikoen for 
psykiske lidelser hos slektninger til folk med alvorlige psykiske lidelser ${ }^{2}$. I praksis tok man utgangspunkt $\mathrm{i}$ alvorlige hospitaliserte tilstander som schizofreni og manisk depressiv sinnslidelse. Mange av studiene, flere også utført i de nordiske land, skaffet informasjon fra nøkkelinformanter og offentlige sykehus. Bare få studier innhentet opplysninger ved direkte intervju.

En studie som skapte mye diskusjon var Faris og Dunhams $^{3}$ undersøkelser av innlagte pasienter i psykiatriske hospitaler i Chicago mellom 1922 og 1934, der man fant at innbyggerne $\mathrm{i}$ de sentrale deler av byen hadde den høyeste innleggelsesfrekvens av schizofreni. Var forklaringen at befolkningen $\mathrm{i}$ de indre bydeler var utsatt for størst sosial påkjenning og disorganisasjon, eller var forklaringen at folk med psykiske lidelser gled nedover den sosiale rangstige? I dag vet vi at det er den siste "driftshypotesen" som forklarer data best.

Den annen verdenskrig skapte et vendepunkt i den psykiatriske epidemiologi. Man hadde oppdaget at psykiske lidelser var hovedgrunnen til at menn ble refusert i det militære. Videre ble man klar over at mer enn halvparten av alle sykehussenger i de vestlige land var belagt med pasienter med psykiske lidelser. I 1946 vedtok Kongressen i USA "The National Mental Health Act", som i 1949 førte til opprettelsen av National Institute of Mental Health. NIMH har hatt stor betydning for utdannelsen av epidemiologiske forskere.

Den psykiatriske epidemiologien fikk, særlig i USA, etter krigen en miljømessig slagside, sterkt påvirket av sosiologisk og antropologisk tenkning. Stirling County-studien ${ }^{4}$ ble påbegynt i 1952 av Alexander og Dorothea Leighton og rekrutterte initialt 1010 voksne som bodde i sydligere deler av det atlantiske Canada. Individene ble undersøkt med et strukturert spørreskjema. Informasjon ble også innhentet fra almenpraktiserende leger. Diagnosen var basert på DSM-I diagnostikk fra 1952. Livstidsprevalensen for alle psykiske lidelser var totalt $20 \%$. I Stirling Countystudien var sosial desintegrasjon hovedvariabelen. Man fikk bekreftet at det var betydelig høyere forekomst av psykisk sykelighet i desintegrerte samfunn, preget av oppløste hjem, få og svake foreninger, mangelfullt lederskap, få fritidsmuligheter så vel som fattigdom, sekularisering og kulturell "forvirring". De desintegrerte lokalsamfunn var ofte fraflyttingsområder, preget av økonomisk tilbakegang med et sviktende næringsgrunnlag.

Midtown Manhattan-studien ${ }^{5}$ ble påbegynt i 1954 av Rennie og Srole. Informasjon ble innsamlet av trenede intervjuere, men ble senere gjennomgått av psykiatere. Den totale livstidsprevalens av psykopatologi var 23\%. Midtown Manhattan-studien var basert på pasienter som var til behandling i sykehus, poliklinikker og hos privatpraktiserende leger og på hjemmeintervju av et utvalg personer. Manhattan var på begynnelsen av 1950-årene på mange vis typisk for de sentrale deler av mange amerikanske storbyer. Hovedhypotesen her, som for øvrig ble bekreftet, var at sosial klasse var den mest sentrale uavhengige variabel. Man fant således en opphopning av psykiske lidelser i lavere sosiale lag. Viktig var det også at psykiske påkjenninger rammet hardest ved lav sosial status.

Hverken Stirling County-studien eller MidtownManhattan-undersøkelsen opererte med psykiatriske diagnoser, men med psykososial svikt (social impairment). Begge disse undersøkelsene viste at bare 17$18 \%$ av den voksne befolkning var uten psykiske symptomer og 30-40\% hadde en klar psykisk lidelse. Når disse studiene og mange andre fant så høy forekomst av psykiatrisk sykelighet i befolkningen, ble selvsagt spørsmålet om undersøkelsene var valide. Dette ble undersøkt allerede på 1950-tallet ved å sammenligne survey-undersøkelser med vurderinger gjort av kliniske psykiatere. Resultatene var nokså klare. Epidemiologiske undersøkelser var valide. Behandlingsbehovet var altså omfattende.

Vi bør også nevne en klinisk studie med et epidemiologisk siktepunkt. Hollingshead og Redlich ${ }^{6}$ studerte sammenhengen mellom sosial klasse og psykiske lidelser i et pasientmateriale fra New Haven, Connecticut. Hovedfunnet var at pasienter fra lavere sosiale lag hadde den høyeste forekomst av psykopatologi. Pasientenes sosiale klasse avgjorde dessuten hvilken behandling pasienten fikk. Pasienter fra lavere sosiale lag ble oftest behandlet med medisiner og elektrostimulasjonsbehandling mens pasienter fra øvre sosiale lag fikk psykoterapi. Man fant også at langt flere fra øvre sosiale klasse søkte psykiatrisk behandling.

\section{NYERE STUDIER}

I løpet av 1970-80 åra har den psykiatriske epidemiologien gått inn i en ny fase. Nå ble det lagt større vekt på spesifikke psykiatriske diagnoser, og den statistiske analysen av data ble mer sofistikert. Man har også fått bedre metoder til å måle sykeligheten i befolkningen. Et instrument, Composite International Diagnostic Interview (CIDI), er utarbeidet av Robins og medarbeidere i samarbeid med WHO og brukes $\mathrm{i}$ dag i en rekke undersøkelser både i Europa og USA. Fordelen med instrumentet er at det kan anvendes av ikke-klinikere etter opplæring.

Et nytt trekk i bildet fra de senere år er også den relativt store epidemiologiske aktivitet på det barnepsykiatriske felt. Jonsson og Kälvesten ${ }^{7}$ hadde allerede i sin klassiske studie fra 1964 av over 200 tilfeldig utvalgte 7-15 årige Stockholmsgutter vist hvor hyppig psykiske lidelser var hos barn. Bare $21 \%$ var symptomfrie mens $25 \%$ hadde såpass alvorlige symptomer at det var behov for barnepsykiatrisk behandling. I en undersøkelse av Rutter et $\mathrm{al}^{8}$ ble over 2000 barn i alderen 10-11 år på Isle of Wight kartlagt medisinsk, psykiatrisk og pedagogisk. Denne undersøkelsen anvendte en meget snever definisjon av "caseness" og fant en prevalens på $6,8 \%$ med dobbelt så høye tall hos guttene som hos jentene. De dominerende forstyrrelse- 
ne var enten av emosjonell art i form av angst, bekymring og fobier særlig hos jentene, og atferdsforstyrrelser i form av aggressiv atferd, skoleskulk og kriminalitet hos guttene. En sammenligning av barn på Isle of Wight med et London-distrikt viste at den psykiatriske sykelighet var dobbelt så høy i indre London som på Wight. Det var åpenbart at risikoen var i større grad knyttet til familieforholdene enn det ytre miljø ${ }^{9}$. En undersøkelse fra Norge av Lavik ${ }^{10}$ på 1970-tallet tok for seg knapt 400 elever i 15-16 års alderen i Oslo og sammenlignet deres psykiske helse med vel 100 ungdommer fra Nord-Østerdalen. Interessant nok var den psykiatriske sykelighet over dobbelt så stor i Oslo som i Østerdalen. I Oslo-utvalget fant man de mest markerte psykiske problemer hos guttene.

Siden er en rekke epidemiologiske undersøkelser av barn utført i vestlige land. Man finner generelt at $10-15 \%$ av barn i landlige og stabile regioner har såpass store psykiske problemer at det kvalifiserer for en psykiatrisk diagnose, mens tallet er $15-20 \%$ i mer ustabile urbane områder. Før puberteten finner man stort sett lik forekomst av depresjon hos de to kjønn, men etter puberteten endrer dette seg med langt flere deprimerte jenter enn gutter. Hos barn er depresjon ofte koblet sammen med angst og atferdsforstyrrelse mens rene depresjoner er relativt sjeldne. De fleste epidemiologer innen psykiatrien er enige om at det har vært en økning av forekomsten av visse psykiske lidelser hos barn, og at atferdsforstyrrelser, stoffmisbruk, depresjon og muligens mani og schizofreni viser en tidligere debut enn før.

ECA-studien (Epidemiological Catchment Area $)^{11,12}$ anvendte det strukturerte intervjuskjemaet DIS med legfolk som trenete intervjuere. Ved intervju $i$ to trinn fikk man ikke bare registrert prevalens, men insidenstall og spesifikke diagnoser. ECA-studien omfattet 20000 personer, hovedsakelig fra New Haven, Baltimore, St. Louis, Durham og Los Angeles og gir et bilde av den psykiatriske sykeligheten i USA på begynnelsen av 1980-åra. 32\% av den voksne befolkningen hadde en eller annen gang hatt en psykisk lidelse, mens 20\% var plaget med en psykisk lidelse på tidspunktet for undersøkelsen. Man fant klare kjønnsforskjeller. Om lag 9\% av mennene ble diagnostisert som alkohol- eller stoffmisbrukere, men bare $2 \%$ av kvinnene. Om lag $4 \%$ av kvinnene og $2 \%$ av mennene hadde en alvorlig depresjon, et uvanlig lavt tall som vi skal diskutere senere. Ett av de mest interessante funn var den høye samvariasjon mellom stoffmisbruk og andre psykiske lidelser. 29\% av personer med en psykisk lidelse hadde også et stoffmisbruk. ECA-studien er blitt lovprist av amerikanerne, men kritisert av andre med hensyn til metodologi. Man har stilt seg tvilende til de høye tallene som er rapportert for schizofreni og tvangsnevrose og de lave tallene for depresjon. Feilkildene har vært tilskrevet svak kvalitet på intervjuene, lav diskriminerende kraft i DIS og de mange falske positive kasus $^{13,14}$.

ECA-studien ble etterfulgt av flere andre undersø- kelser av lignende karakter. Christchurch-studien fra New Zealand studerte den psykiatriske sykeligheten i en by på 300000 innbyggere og tok utgangspunkt $\mathrm{i}$ tilfeldig utvalgte husholdninger. Tallene her adskiller seg på mange vis fra ECA-studien med langt høyere tall for depresjon og alkoholmisbruk ${ }^{15,16}$.

Puerto Rico-studien fra Karibien undersøkte en befolkning på 3 millioner mennesker. Populasjonen her hadde gjennomgått betydelige sosiale forandringer over de siste tiår, fra bygdesamfunn til urbane industrielle samfunn med fattigdom og arbeidsledighet. Livstidsprevalensen for alle psykiske lidelser var $28 \%$ og $16 \%$ de siste 6 måneder $^{17}$.

Edmonton-studien fra Canada på 1980-90 tallet bygger på DIS-intervjuer og GHQ-spørsmål. Utvalget omfattet 3300 personer fra tilfeldig utvalgte husholdninger. Funnene her adskilte seg fra ECA-studien med betydelig høyere tall for alkohol- og stoffmisbruk både hos menn og kvinner og høyere tall for antisosial atferd hos menn. I tråd med ECA-studien fant man betydelig lavere livstidsprevalens hos eldre sammenlignet med yngre individer ${ }^{18,19}$.

Den mest omfattende epidemiologiske studien fra de siste år er The National Comorbidity Survey, utformet av Kessler og medarbeidere ${ }^{20}$. Diagnosene bygget her på DSM-III-R, og det var mulig å sammenligne DSM-IV med ICD-10. Mens ECA-studien i første rekke var en prevalens- og insidensundersøkelse, kombinerer NCS analyser av foreldrepsykopatologi, familierelasjoner, sosialt nettverk og stress. Et tilfeldig utvalg på vel 8000 personer utenfor institusjon fra 48 stater i alderen 15-54 år ble valgt ut. Responsraten var $83 \%$. Man brukte en modifisert versjon av intervjuskjemaet CIDI. 48,7\% rapporterte $\mathrm{i}$ det minste en psykisk lidelse tidligere i livet, og 29,4\% hadde vært plaget av en psykisk forstyrrelse siste året. De hyppigste psykiske lidelsene var alvorlig depresjon, alkoholmisbruk, sosial fobi og enkel fobi. Livstidsprevalensen for markert depresjon (major depression) var 17,1\%, den årlige prevalens $10,3 \%$. Interessant er det at mer enn halvparten av livstidsforstyrrelsene forekom hos $14 \%$ av befolkningen. Disse hadde tre eller flere psykiatriske diagnoser i følge DSM-III-R. Og selv denne gruppen med alvorlige psykiske lidelser hadde bare fått profesjonell hjelp i $40 \%$ av tilfellene. Forekomsten av psykiske plager avtok med økende alder og stigende sosial støtte. Hovedforskjellen mellom ECA og NCS viser seg i prevalenstallene som var $32 \%$ i den første og $49 \%$ i den andre. Noe av forskjellen kan skyldes til dels ulik aldersfordeling og ulike diagnostiske instrumenter.

Mini-Finland helseundersøkelsen omfattet 8000 personer over 30 år, som også ble studert med tanke på somatiske sykdommer i 1978-80. Det ble funnet en prevalens på $17 \%$ for psykiske lidelser med noe høyere tall for kvinner enn for menn. De høyeste prevalenstallene for kvinner var for alderen 50-64 år, mens de høyeste tall for menn ble observert i 60-65 års alderen. De høyeste tall fant man i de lavere sosiale lag av 
befolkningen, særlig østre og nordlige Finland som har svakest økonomi ${ }^{21}$.

Mens de fleste nyere epidemiologiske studier har vist en økende tendens til psykiske lidelser hos yngre mennesker, viser både Mini-Finland undersøkelsen og UKKI-studien fra Finland et annet mønster. I den siste ble tusen personer i 15-64 års alderen undersøkt i 1969-71 og siste gang i 1985-87. I kontrast til hva andre har funnet $i$ andre vestlige land, var de yngre kohorter sunnere enn de eldre. Dette kan kanskje tilskrives de harde tider som den finske befolkningen gikk igjennom etter siste verdenskrig med store materielle erstatninger til Sovjet-Unionen ${ }^{22}$.

I en omfattende nederlandsk studie, The Netherlands Mental Health Survey and Incidence Study, undersøkte man i 1996 et representativt utvalg av over 7000 personer mellom 18 og 64 år med CIDI ${ }^{23,24}$. Undersøkelsen fant at $41,2 \%$ av den voksne befolkningen under 65 år hadde $\mathrm{i}$ det minste en livstidsforstyrrelse $\mathrm{i}$ følge DSM-III-R, og 23,3\% hadde erfart en slik forstyrrelse i foregående år. Det var ingen kjønnsforskjell totalt, men depresjon og angst var langt hyppigere hos kvinner enn menn, som hadde høyere rater av alkoholog stoffmisbruk. Et konsistent mønster for alle psykiske lidelser var at den eldste aldersgruppen fra 55 til 64 år hadde den laveste forekomst. Høyest forekomst av depresjon fant man i 35-44 års gruppen.

I en studie fra Oslo fant man ved CIDI en forekomst av psykiske lidelser på linje med NCS-studien fra USA. Den totale årlige prevalens av psykiske lidelser var på $32,8 \%$, med en livstidsprevalens på 52,4\%. De høyeste tall fant man for depresjon, alkoholmisbruk og sosial fobi. Markert depresjon (major depression) hadde en årlig prevalensrate på 7,3\% og dystymi (nevrotisk depresjon) på 3,8\%, med en livstidsprevalens på hhv. 18 og 10\%. Forekomsten av depresjon, angst og fobi var langt hyppigere hos kvinner enn hos menn ${ }^{25}$. Forekomsten av personlighetsforstyrrelser i Oslomaterialet var også høy med $13,1 \%{ }^{26}$. Oslo-materialet viser at hele $5 \%$ klassifiseres som unnvikende, mens $2,2 \%$ er paranoide og $1,6 \%$ schizoide personligheter. Forekomsten av emosjonelt ustabile forstyrrelser (borderline tilfeller) er lavere enn i amerikanske studier.

Som konklusjon kan man slå fast at både den årlige prevalens og livstidsprevalensen av psykiske lidelser er meget høy i vestlige samfunn. Tar man utgangspunkt i National Comorbidity Survey fra USA, the Netherlands Mental Health Survey and Incidence Study og Oslo-undersøkelsen, som alle har brukt samme metodikk med personlig intervju ved hjelp av måleinstrumentet CIDI, finner man en årlig forekomst av psykiske lidelser på over $30 \%$ og en livstidsprevalens på om lag 50\%. NCS-studien og Oslo-undersøkelsen har nesten identiske tall med unntak for stoffmisbruk, der tallene er meget høyere i USA. Når den hollandske studien viser noe lavere tall, kan det skyldes at man $i$ større grad enn i USA og Oslo har inkludert en rural befolkning.

\section{KJØNN, ALDER, BY OG LAND}

De fleste psykiatrisk epidemiologiske studier viser liten forskjell i total forekomst av psykiske lidelser hos kvinner og menn, men det symptomatiske bildet er ulikt hos de to kjønn. Hos barn før puberteten finner man hyppigst psykiske lidelser hos gutter, men det mest slående er ulikhetene i symptomer. Gutter er "utagerende" med aggresjon og impulsivitet, mens jentene plages av "innadrettet" angst og bekymring. Kvinner har gjennomgående to til tre ganger så høy forekomst av angst og alminnelig depresjon som menn. Den mest ekstreme kjønnsforskjellen finner man ved spiseforstyrrelser, som er meget sjeldne hos menn. Alminnelig depresjon er langt hyppigere hos kvinner enn menn, men ved de typisk manisk depressive eller bipolare tilstander er forskjellen ubetydelig. Menn har på den annen side langt høyere forekomst av alkohol- og stoffmisbruk enn kvinner og også høyere forekomst av antisosial atferd. Det har tidligere vært vanlig å angi at schizofreni forekommer med samme hyppighet hos de to kjønn. Imidlertid viser epidemiologiske data fra de siste 20 år at om lag $60 \%$ av nye tilfeller av schizofreni forekommer hos menn mot $40 \%$ hos kvinner ${ }^{27,28}$.

Et gjennomgående trekk ved nyere psykiatrisk epidemiologi er den økende forekomst av psykiske lidelser hos yngre mennesker. Man har gjennom de siste 40-50 år sett en økning av suicid, alminnelige depresjoner, alkohol- og stoffmisbruk og spiseforstyrrelser i form av bulimi hos den yngre garde $i$ de fleste vestlige samfunn $^{29}$. Enkelte forskere har imidlertid stilt seg tvilende til økningen av depresjoner hos de yngre.

Senil demens, inkludert Alzheimers sykdom, som er den viktigste formen, kan begynne allerede i 40-50 års alderen, men øker sterkt med stigende alder. Hver 4. person over 80 år har senil demens. Begynnelsesalderen for schizofreni er vanligvis i 18-25 års alderen med risikoperiode fra 15-45 år. Bipolare tilstander kan forekomme for første gang gjennom hele livsløpet, men debuterer vanligvis i 20 års alderen. Angsttilstandene, inkludert panikkanfall, generalisert angst og fobier begynner gjerne i 18-25 års alderen, men kan også debutere i barndommen. Somatoforme forstyrrelser begynner gjerne i unge år og kan vare resten av livet. Tvangsnevrotiske symptomer manifesterer seg gjerne i 15-20 års alderen, men kan også oppstå i barndommen. Man ser sjelden tvangssymptomer etter 3540 års alderen uten at disse er ledsagersymptomer til depresjon. Personlighetsforstyrrelser manifesterer seg gjerne $\mathrm{i}$ ung alder, antisosial personlighetsforstyrrelse før puberteten, de øvrige gjerne i 15-18 års alderen.

ECA-studien fant ingen signifikant forskjell mellom land og by når det gjaldt markert depresjon (major depression). Men det vanlige mønster er at forekomsten av psykiske lidelser er høyere i byene enn på landet. Dette gjelder både for barn og voksne. Unntaket er Australia, noe som tyder på at det ikke er selve byen 
som er patologiserende. Mange byer kan ha et godt sosialt miljø. Men alt $\mathrm{i}$ alt finner man at storbyene $\mathrm{i}$ vestlige samfunn ofte fører med seg ustabilitet og et uheldig fritidstilbud med mye alkohol og til dels stoff.

\section{ØKNING AV SINNSLIDELSER?}

I løpet av de siste 200 år har både folk flest og psykiatere stilt seg spørsmål om psykiske lidelser har økt. Dette var Richard Powells oppfatning da han analyserte data fra England mellom 1775 og $1809^{30}$, og i Frankrike var dette et viktig diskusjonstema etter 1820 . De fleste medisinhistorikere er enige om at hjernesyfilis og alkoholmisbruk økte kraftig i det 19. århundre $i$ Vest-Europa. Syfilis var kjent fra middelalderen, men hjernesyfilis med sinnssykdom (paralysis generalis) synes å ha manifestert seg først senere. Alkoholforbruket økte også dramatisk i dette århundret i store deler av Europa og USA, noe som må ha medført et økende antall alkoholmisbrukere. Etter løsrivelsen fra Danmark i 1814 ble alkoholen i Norge frigitt, noe som ga en voldsom økning i forbruket fra ca. 1,5 liter per person per år til ca. 8 liter fram til 1840-50. Alkoholkonsumet medførte ikke bare sosial elendighet, men alkoholisme med delirium tremens og organiske psykoser med økt hospitalisering.

Etter den siste verdenskrigen er det stadig blitt hevdet at de psykiske lidelser øker. Det foreligger imidlertid få objektive data som klart kan bekrefte slike tendenser. Først i nyere tid har man fått en mer pålitelig diagnostikk, som vil gjøre det mulig å sammenligne dagens psykiatriske panorama med framtidens. De fleste epidemiologer er enige om at det i løpet av de siste 50 år har skjedd en økning av alkohol- og stoffmisbruk, antisosial atferd og sannsynligvis spiseforstyrrelser i form av bulimi i de vestlige land. Mange vil også mene at alminnelige depresjoner har økt. Murphy et $\mathrm{al}^{31}$ rapporterte at prevalensen av depresjon var nokså stabil med ca. 5\% i tre utvalg fra 1952, 1970 og 1992. Men i det siste utvalget var det en tendens til økt frekvens hos yngre med minsket frekvens hos eldre. Dessuten hadde ratioen kvinner/menn økt. Vi har ingen data som dokumenterer økning av nevrotiske forstyrrelser. Tvert imot tyder erfaring fra klinisk praksis på at de klassiske nevrotiske bildene er blitt mindre hyppige. Heller ikke foreligger det noen økning av schizofreni og manisk depressive tilstander. Økningen av senile tilstander skyldes at det er blitt flere eldre i samfunnet, men det foreligger ingen økt insidens. Den antatte økningen av visse sinnslidelser har særlig rammet barn og unge - en bekymringsfull utvikling. Tvilerne vil hevde at økningen er tilsynelatende og skyldes endring i diagnostisk praksis, mindre toleranse og eventuelt det faktum at eldre mennesker har vanskeligere for å huske tidligere hendelser av angst og depresjon, noe som fører til underrapportering av psykiske lidelser hos eldre. Imidlertid har suicidratene økt i mange vestlige land etter 1970-tallet, en økning som særlig har forekommet blant yngre, særlig menn, og bekrefter våre antagelser. Når det gjelder alkohol- og stoffmisbruk har forbruket av alkohol steget gjennom de siste tiår, og fra 1960-70 tallet har man sett en betydelig økning av stoffmisbruk på begge sider av Atlanteren.

Mange av disse studiene har sine svakheter, og en viktig feilkilde er selvsagt at yngre og eldre mennesker kan vurdere depressive symptomer forskjellig. Yngre kan ha lettere for å fortelle om sin depresjon enn eldre. Eldre kan ha tendens til å glemme en tidligere depresjon. På den annen side bekrefter selvmordsstatistikken de epidemiologiske intervjudata. Mellom 1950 og 1995 er selvmordsraten i USA blant 20-åringer blitt mer enn firedoblet, mens tallene for 20-25 åringer er nesten tredoblet. Mesteparten av denne økningen har forekommet hos unge menn, selv om unge kvinner gjør selvmordsforsøk langt hyppigere. Økningen i selvmordstall hos unge mennesker er altså ikke en del av den alminnelige økningen av selvmord blant amerikanere. Tvert imot, den eksplosive økningen hos unge mennesker har gått sammen med en tilsvarende nedgang i selvmord blant eldre.

Tall for depresjon og selvmord samsvarer også med andre sosiale forhold. Undersøkelser fra USA på 1940-50 tallet fant at yngre mennesker den gang var lykkeligere enn eldre. I 1975 var alder og lykkefølelse ukorrelert. I 1999 var derimot yngre mennesker mer ulykkelige enn eldre. Jo yngre man var desto verre syntes man livssituasjonen var blitt i løpet av de siste tiår. De yngre hadde også mer hodepine, fordøyelsesproblemer og søvnløshet og den alminnelige tilfredshet med livet var mindre god ${ }^{32}$.

\section{KOMORBIDITETENS EPIDEMIOLOGI}

I lang tid har klinikere vært klar over at mange psykiske lidelser i perioder kunne være blandet opp med andre symptomer. En pasient med en tvangsnevrose kunne ha angst, til andre tider depresjon. En pasient med depresjon kunne bli paranoid. Men det var først etter at man fikk DSM-III, der forskjellige psykiske syndromer ble spesifisert med inklusjons- og eksklusjonskriterier, at man begynte å snakke om komorbiditet. Dette uttrykket stammet egentlig fra indremedisinen og dreiet seg opprinnelig om pasienter med to eller flere forskjellige sykdommer, for eksempel diabetes og hjerteinfarkt. Mens man tidligere gjerne hadde ført opp en hoveddiagnose med eventuelle bidiagnoser i parentes, ble det nå mer og mer vanlig å diagnostisere flere "sykdommer" samtidig.

Begrepet komorbiditet er problematisk og kanskje ofte misvisende i psykiatrien. En del psykiske lidelser har klare symptomer som forsvarer en klar diagnose. Men i en rekke tilfeller vil pasienter under stress og påkjenninger utvikle forskjellige symptomer fra angst til tvang og depresjon, og det blir litt tilfeldig hvilke symptomer som skal få førsterang. I mange tilfeller 
finner vi pasienter der angst og depresjon går hånd $\mathrm{i}$ hånd. Den hyppigste diagnosen på en psykiatrisk poliklinikk ville sannsynligvis være blandet angst depressiv tilstand. Men i dag tvinger diagnosesystemet oss til en ofte kunstig oppsplitting, noe som også kan gi nybegynnere i faget, som er uten klinisk erfaring, et inntrykk av at det eksisterer så mange forskjellige sykdommer, sågar med sin selvstendige etiologi.

Den mest sentrale psykiatriske epidemiologiske studie i nyere tid, National Comorbidity Survey, hadde faktisk til hovedhensikt å studere komorbiditet. Studien viste at komorbiditet blant psykiske forstyrrelser var meget vanlig. Over halvparten av pasienter i behandling får mer enn en diagnose, og tre av fire pasienter som behandles for stoffmisbruk eller stoffavhengighet har også en annen psykiatrisk diagnose. Og halvparten av alle pasienter med en livstids psykisk lidelse har hatt en tidligere psykisk lidelse. Erfaring viser at behandlingen er vanskeligere og prognosen dårligere når man har flere diagnoser, noe som er naturlig. Flere diagnoser sier jo bare at man er mer syk enn en pasient med bare en diagnose.

For å få et klart bilde av komorbiditeten må man studere tilfeldige utvalg fra befolkningen. Kliniske utvalg vil ofte overbetone komorbiditeten fordi komorbiditet er knyttet til hjelpsøkende atferd. Over 50\% av deltagerne i ECA-studien med en livstidshistorie på minst en psykisk lidelse $\mathrm{i}$ følge DSM-III hadde en diagnose nummer to, $52 \%$ av alkoholmisbrukerne fikk en ny diagnose og $25 \%$ av stoffmisbrukerne hadde en slik diagnose. Lignende resultater ble rapportert i NCS-studien. 56\% av personene med en livstids DSMIII-R diagnose hadde en eller flere andre diagnoser ${ }^{20}$.

Både ECA og NCS-studien viser at det er stor komorbiditet mellom forskjellige depressive tilstander og mellom slike tilstander og angst. Videre, på tross av at den kliniske litteraturen peker på stor komorbiditet mellom affektive lidelser og stoff- og alkoholmisbruk og mellom angst og stoffmisbruk, er disse sammenhengene mindre sterke i den alminnelige befolkning.

Hva er så årsaken til komorbiditet? Man kan tenke seg flere årsaker. En mulighet er at den primære psykiske lidelse influerer direkte på begynnelsen av en annen. Et eksempel er agorafobi sekundært til panikkforstyrrelse som utvikler seg når et panikkanfall fører til invalidiserende frykt for nye anfall i situasjoner hvor det er vanskelig å få hjelp. Et annet eksempel er kronisk blandet angst og depresjon som kan forekomme når kronisk angst fører til håpløshet og hjelpeløshet. En annen mulighet er at visse psykiske lidelser kan forekomme som en indirekte konsekvens av andre. Stoffmisbruk kan utvikle seg som et resultat av selvmedisinering for en psykisk lidelse. Pasienten har angst eller depresjon og tar alkohol eller stoff for å døyve plagene med det resultat at pasienten også utvikler stoffmisbruk. Konsekvensen av stor komorbiditet er for det første at behandlingen blir vanskeligere og for det andre at prognosen blir dårligere.

Det bør også nevnes at DSM-systemet er i sterk vekst på differensialdiagnoser, en tendens som er blitt enda sterkere i DSM-III-R og DSM-IV, som eliminerte mange diagnostiske hierarkier og økte raten for multiple diagnoser og komorbiditet. Derfor kan hele problemet komorbiditet bli overdrevet, for eksempel ved at kriteriene for bestemte psykiatriske symptomer er altfor snevert definert, at man har for mange diagnoser, og at man har fjernet diagnostiske hierarkier.

\section{REFERANSER}

1. Dahl L. Bidrag til kundskab om de sindssyge i Norge. Christiania, 1859.

2. Zerbin-Rüdin E, Kendler KS. Ernst Rüdin (1874-1952) and his genealogic-demographic department in Münich (1917-1986). An introduction to their family studies of schizophrenia. Am J Med Genet 1996; 67: 332-7.

3. Faris REL, Dunham HW. Mental disorders in urban areas. Chicago, 1939.

4. Leighton DC, Harding JS, Macklin DB, Macmillon AM, Leighton AH. The character of danger: Psychiatric symptoms in selected communities. New York: Basic Books, 1963.

5. Srole L, Langner TS, Michael ST, Opler MK, Rennie TAC. Mental health in the metropolis: The Midtown Manhattan study. New York: McGraw-Hill, 1962.

6. Hollingshead AB, Redlich FC. Social class and mental illness: a community study. New York: Wiley, 1958.

7. Jonsson G, Kalvesten AL. 222 Stockholmpojkar. Uppsala: Almquist \& Wiksell, 1964.

8. Rutter M, Tizard J, Whitmore K. Education, health and behaviour. London: Longman, 1970.

9. Rutter M, Yale B, Quintin D et al. Attainment and adjustment in two geographical areas. III. Some factors accounting for area differences. Br J Psychiatry 1975; 126: 520-33.

10. Lavik NJ. Ungdoms mentale helse. Oslo: Universitetsforlaget, 1976.

11. Robins LN, Helzer JE, Weissman MM, Orwaschel H, Gruenberg E, Bruke JD Jr, Regier DA. Lifetime prevalence of specific psychiatric disorders in three sites. Arch Gen Psychiatry 1984; 41: 949-58.

12. Blazer D, George LK, Landerman R, Pennybacker M, Melville ML, Woodbury M, Manton KG, Jordan K, Locke B. Psychiatric disorders: a rural/urban comparison. Arch Gen Psychiatry 1986; 42: 651-6. 
13. Burvill PW. An appraisal of the NIMH epidemiologic catchment area program. Aust N Z J Psychiatry 1987; 21: 175-84.

14. Parker G. Are the lifetime prevalence estimates in the ECA study accurate? Psychol Med 1987; 17: $275-82$.

15. Wells JE, Bushnell JA, Hornblow AR, Joyce PR, Oakley-Browne MA. Christchurch psychiatric epidemiology study, part I: methodology and lifetime prevalence for specific psychiatric disorders. Aust N Z J Psychiatry 1989; 23: 315-26.

16. Oakley-Browne MA, Joyce PR, Wells JE, Bushell JA, Hornblow AR. Christchurch psychiatric epidemiological study. Part II: Six months and other periode prevalence of specific psychiatric disorder. Aust $N Z J$ Psychiatry 1989; 23: 327-40.

17. Canino GJ, Bird HR, Shrout PE, Rubio-Stipec M, Bravo M, Martinez R, Sesman M, Guevara LM. The prevalence of specific psychiatric disorders in Puerto Rico. Arch Gen Psychiatry 1987; 44: 727-35.

18. Bland RC, Newman SC, Orn H (eds). Epidemiology of psychiatric disorders in Edmonton. Acta Psychiatr Scand Suppl 1988; 338.

19. Bland RC, Newman SC, Russel JM, Orn HT (eds). Epidemiology of psychiatric disorders in Edmonton: Phenomenology and comorbidity. Acta Psychiatr Scand Suppl 1994; 376.

20. Kessler RC, McGonagle KA, Zhao S, Nelson CB, Hughes M, Eshleman S, Wittchen H-U, Kendler KS. Lifetime and 12-month prevalence of DSM-III-R psychiatric disorders in the United States: results from the National Comorbidity Survey. Arch Gen Psychiatry 1994; 51: 8-19.

21. Lehtinen V, Joukama A, Lathela K, Raitasalo R, Jyrkinen E, Maatela J, Aromaa A. Prevalence of mental disorders among adults in Finland: basic results from the Mini-Finland Health Survey. Acta Psychiatr Scand 1990; 81: 418-25.

22. Lehtinen V, Veijola J, Lindholm T, Moring J, Puuka P, Vaisanen E. Incidence of mental disorders in the Finnish UKKI study. Br J Psychiatry 1996; 168: 672-8.

23. Bijl RV, van Zessen G, Ravelli A, de Rijk K, Langendoen Y. The Netherlands mental health survey and incidence study (NEMESIS): objectives and design. Soc Psychiatry Psychiatr Epidemiol 1998; 33: 581-6.

24. Bijl RV, Ravelli A, van Zessen G. Prevalence of psychiatric disorder in the general population: results of the Netherlands mental health survey and incidence (NEMESIS). Soc Psychiatry Psychiatr Epidemiol 1998; 33: 587-95.

25. Kringlen E, Torgersen S, Cramer V. A Norwegian psychiatric epidemiological study. Am J Psychiatry 2001; 158: 1091-8.

26. Torgersen S, Kringlen E, Cramer V. The prevalence of personality disorders in a community sample. Arch Gen Psychiatry 2001; 58: 590-6.

27. Angemeyer MC, Kühn L. Gender differences in age at onset of schizophrenia: an overview. Eur Arch Psychiatry Neurol Sci 1988; 237: 351-64.

28. Iacono WG, Beiser M. Where are the women in first-episode studies of schizophrenia. Schizophr Bull 1992; 18: 471-80.

29. Smith DJ, Rutter M. Time trends in psychosocial disorders in youth. In: Rutter M, Smith DJ (eds). Psychosocial disorders in young people. Chichester: Wiley, 1995.

30. Powell R. Sitert etter Lewis A. Demographic aspects of mental disorder. In: Lewis A. Inquiries in psychiatry. London: Ruthledge.

31. Murphy JM, Murphy JM, Laird NM, Monson RR, Sobol AM, Leighton AH. Incidence of depression in the Stirling County Study: historical and comparative perspectives. Psychol Med 2000; 30: 505-14.

32. Putman RD. Bowling alone: the collapse and revival of American community. New York: Simon \& Schuster, 2000. 